\title{
PUDARNYA KUASA NEGARA: ANALISIS CERPEN-CERPEN SENO GUMIRA AJIDARMA DALAM PERSPEKTIF FOUCAULT
}

\author{
Akhmad Rizqi Turama \\ Universitas Sriwijaya \\ a.rizqiturama@gmail.com
}

DOI:

\begin{tabular}{|c|c|}
\hline $\begin{array}{l}\text { Article Info } \\
\text { Article history: }\end{array}$ & $\begin{array}{l}\text { ABSTRACT } \\
\text { Based on the opinion that says literature reflects the reality, there is a } \\
\text { question about whether or not there are several changes in state's } \\
\text { position in short story before and after reformation. Two short stories } \\
\text { chosen to be analyzed are Seno Gumira Ajidarma's Saksi Mata and } \\
\text { Aku, Pembunuh Munir. The analysis used by using Foucault's } \\
\text { perspective. The result of the analysis shows that there are changes } \\
\text { in state's power after Indonesian reformation. This is shown by at least } \\
\text { five things, they are the eye witness motivation, the judges' prestige, } \\
\text { the main character's alignments, the antagonist's appearance, and the } \\
\text { court as state's symbol. } \\
\text { Keywords: Foucault, Short Story, Seno Gumira Ajidarma } \\
\text { ABSTRAK } \\
\text { Merujuk pada pendapat bahwa sastra mencerminkan realitas, muncul } \\
\text { sebuah masalah mengenai ada tidaknya perubahan posisi negara } \\
\text { dalam cerpen sebelum dan sesudah reformasi. Dua cerpen yang } \\
\text { dijadikan bahan analisis adalah Saksi Mata dan Aku, Pembunuh } \\
\text { Munir karya Seno Gumira Ajidarma. Analisis dilakukan dengan } \\
\text { menggunakan perspektif Foucault. Hasil analisis menunjukkan bahwa } \\
\text { terjadi pergeseran kekuasaan negara setelah reformasi. Hal ini } \\
\text { ditunjukkan terutama dalam lima hal, yaitu motif kehadiran saksi di } \\
\text { pengadilan, wibawa hakim, keberpihakan tokoh utama, wujud } \\
\text { penjahat, dan pengadilan sebagai lambang negara. } \\
\text { Kata Kunci : Foucault, Cerpen, Seno Gumira Ajidarma }\end{array}$ \\
\hline
\end{tabular}

\section{PENDAHULUAN}

Meskipun karya sastra dianggap sebagai hasil dari imajinasi seseorang, memperhatikan karya-karya sastra (termasuk cerpen) tidak bisa dilepaskan dari realitasrealitas sosial yang terdapat di sekitarnya karena di dalam karya sastra pasti terkandung unsur realitas tersebut. Seperti yang dinyatakan oleh Scholes (dikutip Hasanuddin, 1996:68) yang mengatakan bahwa orang tidak mungkin melihat realitas tanpa interpretasi pribadi yang mungkin berhubungan dengan imajinasi, dan orang tidak mungkin berimajinasi tanpa pengetahuan suatu realitas. Berarti tidak ada imajinasi yang murni imajinasi tanpa terpengaruh oleh realitas sosial di sekitarnya. Semakin besar perubahan sosial yang terjadi, maka semakin besar pula kemungkinan pengaruhnya terhadap karya-karya sastra.

Salah satu momen perubahan sosial tersebut terjadi pada tahun 1998 ketika rezim 
Orde Baru runtuh dan digantikan dengan rezim reformasi. Orde Baru identik dengan rezim yang otoriter, terutama dengan hal-hal yang berkaitan dengan kekuasaan negara. Sementara reformasi dianggap sebagai suatu era yang membuka kebebasan dan keterbukaan, hal-hal yang berkaitan dengan kekuasaan negara tidak lagi menjadi sesuatu yang ditabukan dan dilindungi secara otoriter oleh pemerintahnya. Berangkat dari pemahaman Eagleton (2002:7) yang secara tegas menyatakan bahwa karya sastra adalah bentuk-bentuk persepsi, cara khusus dalam memandang dunia; dan juga memiliki relasi dengan cara memandang realitas yang menjadi mentalitas atau ideologi sosial suatu zaman, maka dapat diasumsikan bahwa setelah pergantian rezim tersebut karya-karya sastra juga mengalami pergeseran dalam memandang dunia.

Asumsi tersebut menimbulkan adanya ketertarikan untuk meniliti karya-karya sastra, terutama cerpen, yang lahir sebelum dan sesudah pergantian rezim tersebut dan membuktikan kebenaran pendapat bahwa sastra terpengaruh oleh realitas sosial. Dalam kaitannya dengan hal tersebut, penulis memilih dua cerpen karya Seno Gumira Ajidarma. Cerpen pertama berjudul Saksi Mata yang ditulis pada tahun 1992 dan dianggap sebagai representasi zaman Orde Baru. Cerpen kedua berjudul Aku, Pembunuh Munir yang ditulis pada tahun 2013 dan dianggap sebagai representasi dari zaman reformasi setelah Orde Baru runtuh. Adapun pemilihan kedua cerpen ini adalah dengan menggunakan metode purposive sampling, sebagaimana yang dijelaskan oleh Narbuko dan Abu Achmadi (2010:116) bahwa teknik ini berdasarkan pada ciri-ciri atau sifat-sifat tertentu yang diperkirakan mempunyai sangkut paut erat dengan ciri-ciri atau sifatsifat yang ada dalam populasi yang diketahui sebelumnya. Dalam teknik purposive sampling ini, penilaian dan pertimbangan peneliti memegang peranan penting karena akan menentukan pengambilan objek. Hal tersebut dikemukakan oleh Sedarmayanti dan Syarifudin Hidayat (2002:131) yang menyatakan bahwa dalam purposive sampling pertimbangan peneliti memegang peranan, bahkan menentukan dalam pengambilan sekumpulan objek untuk diteliti. Dengan berdasarkan pertimbangan bahwa kedua cerpen tersebut cukup merepresentasikan posisi dan kekuasaan negara di dalam karya sastra, maka dipilihlah kedua cerpen seperti yang telah diungkapkan. Penulis juga sengaja mengambil karya yang berasal dari satu pengarang karena beranggapan bahwa realitas sosial, pergantian rezim, mempengaruhi diri seorang pengarang dalam berkarya. Sehingga dengan pemilihan satu pengarang saja, diharapkan dapat tergambar bahwa pandangan dunia pengarang pun bisa berubah, jika asumsi di awal terbukti.

Dari latar belakang yang telah dipaparkan, maka masalah dalam makalah ini adalah bagaimana wujud representasi kekuasaan negara dalam cerpen-cerpen Seno Gumira Ajidarma sebelum dan sesudah reformasi.

\section{METODE PENELITIAN}

Teori Kekuasaan Foucault

Foucault menguraikan kekuasaan melalui pemikiran bahwa paradigma politik tradisional selalu berorientasi pada legitimasi. Kekuasaan merupakan sesuatu 
yang dilegitimasikan secara metafisis oleh negara, sehingga memungkinkan untuk menjadi sebuah kewajiban yang harus dipatuhi bagi seluruh warga di dalam suatu negara. Kekuasaan mengandaikan penguasa berarti berhak melarang (Sarup, 2011:111). Di dalam kekuasaan modern, semua bekerja melalui konstruksi kapasitas dan mode aktivitas "baru", bukan melalui pembatasan terhadap apa yang ada sebelumnya.

Foucault mengungkapkan bahwa kekuasaan bukanlah sesuatu yang dimiliki atau kemampuan dalam mengatasi hal apapun. Kekuasaan bukanlah sesuatu pesanan atau melayani kepentingan tertentu. Foucault menekankan bahwa interaksi kekuasaan tidak hanya diformulasikan sebagai milik individu atau kelas. Kekuasaan bukan komoditas yang bisa dicapai. Kekuasaan bersifat jejaring; yang menyebar luas ke berbagai lini. Sehingga kekuasaan bisa ditemukan dalam segala bidang interaksi manusia: keluarga, politik, ekonomi, sosial, agama dan sebagainya. Penelitian Foucault tentang sejarah orang-orang gila: tentang mereka yang ditolak masyarakat, berhasil mengungkap formasi-formasi bahasa dan diskursus yang telah menciptakan konsep pihak lain (the other) untuk hal ini. Foucault mengatakan analisis kekuasaan seharusnya tidak memusatkan perhatian pada tingkat tujuan sadar, tapi pada poin penerapan kekuasaan. Dengan kata lain, ia ingin mengubah titik perhatian dari pertanyaan, seperti Siapa yang memiliki kekuasaan? Atau "Apa tujuan atau maksud pemegang kekuasaan?" ke proses-proses yang membentuk subjek sebagai hasil pengaruh kekuasaan (Sarup, 2011:112).
Dalam hal ini, kekuasaan dipahami sebagai upaya yang keberadaannya mampu menembus berbagai tempat, yang di sana terdapat sistem, aturan, susunan dan regulasi. Kekuasaan ini tidak datang dari luar, melainkan kekuasaan menentukan susunan, aturan dan hubungan-hubungan dari dalam dan memungkinkan semuanya terjadi (Foucault, 2000:144). Dengan demikian, kekuasaan merupakan muara dari segala kegiatan manusia dan bentuk-bentuk relasinya dengan manusia-manusia lainnya. Terdapatnya pengakuan dari berbagai unsur struktur-struktur yang menjalankan fungsi tertentu merupakan asal muasal kekuasaan. Tujuan gagasan kekuasaan sebagai suatu strategi dan mekanisme berkuasa ialah membentuk setiap diri manusia agar memiliki dedikasi dan disiplin diri, supaya menjadi pribadi yang produktif sesuai dengan maksud dari kekuasaan tertentu.

\section{PEMBAHASAN}

\section{Motif Kehadiran Saksi di Pengadilan}

Kedua cerpen ini sama-sama mengangkat masalah hukum di dalam ceritanya. Dua-duanya pun menghadirkan saksi di dalam persidangan, tapi kehadiran saksi di dalam masing-masing cerpen memiliki motif yang berbeda. Pada cerpen Saksi Mata sang saksi datang ke pengadilan dengan sukarela dan karena panggilan hati nuraninya, bahkan dijelaskan bahwa sang saksi datang demi keadilan dan kebenaran. Berikut ini kutipan dari adegan yang menunjukkan hal tersebut.

"Sekali lagi, apakah saudara Saksi Mata masih bersedia bersaksi?"

"Saya Pak."

"Kenapa?" 
"Demi keadilan dan kebenaran Pak."

(Ajidarma, 1992)

Hal tersebut menjadi sangat berbeda dengan motif kehadiran saksi di dalam cerpen yang berikutnya. Di dalam cerpen kedua, Aku, Pembunuh Munir, saksi hadir bukan demi membela kebenaran dan keadilan, malah sebaliknya. Saksi yang hadir hanyalah boneka yang dikendalikan oleh sang pembunuh munir. Seno Gumira Ajidarma juga bahkan menuliskan dialog antara hakim dan saksi yang terkesan konyol dan tidak logis. Dialog yang semacam itu dimunculkan untuk memberi kesan bahwa tidak ada niat yang baik dari sang saksi dalam kehadirannya di persidangan. Hal tersebut dipertegas lagi oleh narator cerpen (tokoh utama) sebagaimana yang ada dalam kutipan berikut.

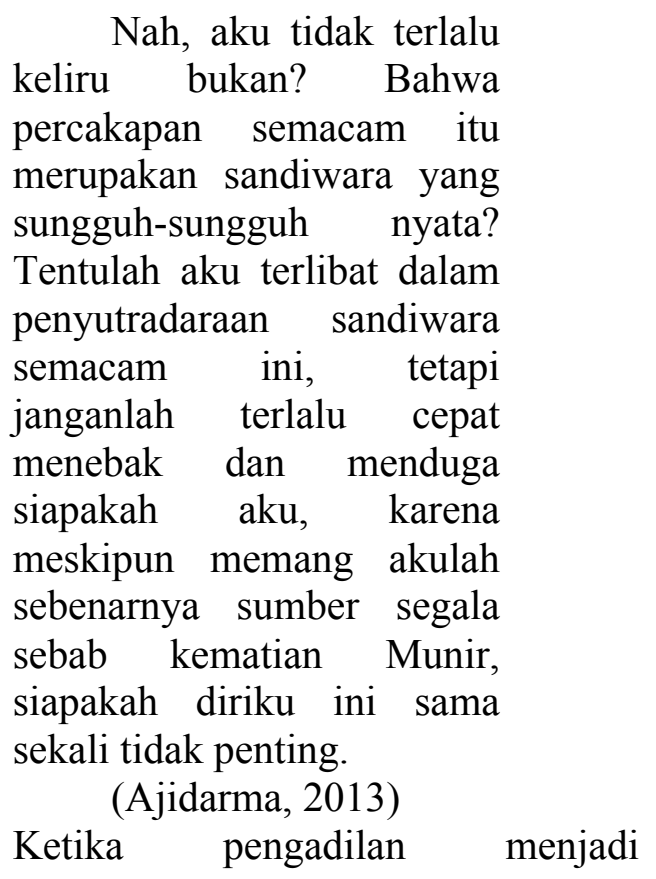
representasi negara di dalam cerpen ini, maka motif kehadiran saksi menjadi penting untuk dibahas. Sebagaimana yang telah dijelaskan bahwa dalam rezim Orde Baru yang diwakili oleh Saksi Mata, saksi datang demi keadilan dan kebenaran. Itu berarti ada sebuah keseganan dan harapan bahwa pengadilan bisa menjadi alat untuk menegakkan keadilan. Pengadilan sebagai wakil negara masih memiliki wibawa yang tinggi di mata masyarakatnya. Hal ini bertolak belakang dengan motif kehadiran saksi pada cerpen kedua yang hanya sebagai boneka dan pemain drama. Cerpen kedua yang mewakili era reformasi menunjukkan bahwa pengadilan hanya sebagai sebuah panggung sandiwara bagi saksi. Negara yang dilambangkan dengan pengadilan tidak lagi dihormati sebagai lembaga yang bisa memberikan keadilan. Sebaliknya, justru keadilan dipermainkan sebagai sandiwara di dalam pengadilan itu.

\section{Wibawa Hakim sebagai Perangkat Negara}

Pada cerpen pertama yang mewakili rezim Orde Baru, ada empat kali adegan hakim mengetuk-ngetuk palunya. Setelah hakim mengetukkan palunya, semua orang yang berbicara menjadi tenang dan diam. Berikut ini kutipan pada saat adegan hakim mengetuk palunya untuk yang pertama kali. "Bapak Hakim Yang Mulia, yang segera tersadar, mengetuk-ngetukkan palunya. dengan sisa wibawa yang masih ada ia mencoba menenangkan keadaan." (Ajidarma, 1992). Ketika suasana di persidangan kembali bergemuruh, hakim untuk kedua kalinya mengetukkan palu sebagaimana yang ada dalam kutipan berikut. "Hakim mengetuk-ngetukkan palunya. Suara lebah menghilang." (Ajidarma, 1992). Begitu pula pada kali ketiga dan keempat. "Lagi-lagi hadirin ribut dan saling bergunjing seperti di warung kopi. Lagi-lagi Bapak Hakim Yang Mulia mesti mengetuk-ngetukkan palu 
supaya orang banyak itu menjadi tenang." (Ajidarma, 1992). "Bapak Hakim Yang Mulia segera mengetukkan palu wasiatnya. (Ajidarma, 1992).

Seperti yang telah dinyatakan bahwa setiap kali hakim mengetukkan palunya, setiap kali itu pula peserta sidang menjadi tenang. Peristiwa tersebut dapat diartikan bahwa hakim memiliki wibawa yang diakui oleh segenap hadirin. Ketika hakim dianggap sebagai representasi alat negara, berarti kuasa negara masih sangat dominan dan diterima oleh masyarakat kewibawaannya. Hal inilah yang tidak lagi didapatkan di dalam cerpen kedua yang merupakan produk pada zaman reformasi. Tidak ada lagi penjelasan mengenai wibawa hakim. Dominasi alat negara sudah memudar. Lebih lanjut, hakim malah mengikuti saja drama yang dimainkan oleh saksi seperti yang dijelaskan pada poin sebelumnya. Berarti bagian ini juga menunjukkan memudarnya kesukarelaan penerimaan masyarakat pada dominasi alat negara.

\section{Tokoh Utama sebagai Representasi Keberpihakan}

Dalam cerpen pertama, yang menjadi tokoh utama adalah seorang saksi mata yang tetap saja hadir dalam persidangan walaupun matanya telah dicongkel dan mengeluarkan darah.

Saksi mata itu datang tanpa mata. Ia berjalan tertatihtatih di tengah ruang pengadilan dengan tangan meraba-raba udara. Dari lobang pada bekas tempat kedua matanya mengucur darah yang begitu merah bagaikan tiada warna merah yang lebih merah dari merahnya darah yang mengucur perlahan-lahan dan terus menerus dari lobang mata itu.

(Ajidarma, 1992)

Tokoh utama pada cerpen pertama yang protagonis sangat berbeda dengan tokoh utama pada cerpen kedua yang antagonis. Berbeda dengan saksi mata yang mencoba membela keadilan, tokoh utama di cerpen kedua justru adalah seorang pembunuh. "Aku adalah anjing kurap, karena itu aku membunuh Munir.” (Ajidarma, 2013). Pusat pengisahan masing-masing cerpen menunjukkan keberpihakan yang berbeda. Cerpen pertama yang berpihak pada lembaga negara, cerpen kedua justru berpihak antinegara. Cerpen pertama menjelaskan pentingnya untuk membela kebenaran. Cerpen kedua justru memberikan pembenaran atas pembunuhan yang dilakukan. Di cerpen kedua sang pelaku membela diri dengan mengatakan bahwa dia juga adalah manusia yang juga memiliki rasa kasih sayang. Pelaku menyatakan diri hanya jahat di satu sisi, tapi di sisi lain ia juga sama seperti yang lain-lain. Dengan pernyataan itu sang pelaku memberikan pembenaran atas kelakukannya yang menentang negara. Selama kepentingannya dan kepentingankepentingan orang lain tidak terganggu, maka perbuatannya bisa dibenarkan. Jadi, di sini dijelaskan bahwa ada kuasa negara yang terdegradasi. Digantikan dengan kuasa kepentingan, meskipun kepentingan itu adalah kepentingan yang busuk sebagaimana yang dinyatakan di dalam cerpen. Ketika di cerpen pertama negara diagungkan, di cerpen kedua negara justru dijadikan alat untuk melanggengkan kepentingan. 
Wujud Penjahat dan Kemampuan Negara

Cerpen pertama mengisahkan bahwa sang saksi mata yang hendak menyampaikan kebenaran di hadapan hukum dipersulit langkahnya oleh penjahat yang kemudian mencongkel matanya dengan sendok.

"Mukanya ditutupi?"

"Iya Pak, cuma kelihatan matanya."

"Aaaah, saya tahu! Ninja kan?'

"Nah, itu ninja! Mereka itulah yang mengambil mata saya dengan sendok!"

(Ajidarma, 1992)

Pada cerpen kedua, juga ada yang menjegal langkah Munir untuk menguak kebenaran, namun wujudnya adalah berbeda. Wujudnya bukanlah ninja sebagaimana ada dalam cerpen pertama. Wujud yang dimunculkan sebagai pembungkam kebenaran di depan hukum ini adalah anjing kurap. "Aku adalah anjing kurap, karena itu aku membunuh Munir.” (Ajidarma, 2013). Tentu saja keduanya, baik ninja maupun anjing kurap, hanyalah metafora yang digunakan oleh penulis. Namun jika ditelaah lebih lanjut bisa ditemukan adanya unsur kemampuan negara yang disinggung dalam metafor itu. Ketika yang bertindak jahat adalah ninja, yang dikenal sebagai orangorang yang wajahnya tak kelihatan dan terlatih datang dan menghilang begitu saja, maka akan ada pemakluman jika negara tidak mampu menangkap penjahat-penjahat itu. Hanya saja, ketika yang melakukan kejahatan adalah seekor anjing kurap, anjing yang boleh dikatakan sebagai anjing yang paling hina dan tidak berdaya, maka ini menjadi ejekan bagi negara ketika tidak mampu menangkapnya. Di akhir cerita yang kedua sang tokoh utama mengatakan bahwa dirinya adalah anjing kurap selama tidak mau mengakui kejahatannya. Pada kenyataannya memang tidak ada penjahat yang mengakui kejahatannya. Cerpen kedua yang seolah memaksa sang pelaku kejahatan untuk mengaku dan menampilkan diri, justru mempertegas ketidakmampuan negara dalam menciduk penjahat yang selevel dengan anjing kurap.

\section{Pengadilan sebagai Lambang Negara}

Pengadilan pun dalam cerpen ini dapat dianggap sebagai lambang negara. Dalam cerpen pertama lambang negara ini begitu dihargai sehingga ketika ada yang hendak menyatakan kebenaran di hadapan lambang negara ini, para penjahat melakukan tindakan keji terhadap sang saksi.

Ketika hari sudah menjadi malam, saksi mata yang sudah tidak bermata itu berdoa sebelum tidur. Ia berdoa agar kehidupan yang fana ini baik-baik saja adanya, agar segala sesuatu berjalan dengan mulus dan semua orang berbahagia. Pada waktu tidur lagi-lagi ia bermimpi, lima orang berseragam Ninja mencabut lidahnya-kali ini menggunakan catut.

(Ajidarma, 1992).

Hal tersebut sangat berbeda dengan apa yang terjadi dalam cerpen kedua, ketika pengadilan sebagai lambang negara hanya dijadikan bahan olok-olok dan menjadi panggung sandiwara. Lebih lanjut dinyatakan bahwa panggung drama itu disutradarai oleh seorang penjahat yang tentu saja menentang negara.

Sehingga terjadilah kegemparan yang berlanjut dengan drama pengadilan. 
Drama, ya, drama dalam dua pengertian: dapat disebut drama karena memenuhi persyaratan dramatik dalam seni pertunjukan; dan bisa disebut drama karena penuh dengan kepura-puraan, bersandiwara dalam kehidupan sebenarnya. (Ajidarma, 2013)

\section{KESIMPULAN}

Berdasarkan analisis yang telah dilakukan, maka jelaslah bahwa dalam cerita menunjukkan adanya degradasi dalam kuasa negara. Masyarakat tidak sepenuhnya lagi menerima dengan sukarela dominasi negara, sebaliknya masyarakat malah mempermainkan dan memutarbalikkan lambang-lambang negara tersebut. Maka dapat disimpulkan dari penjelasanpenjelasan yang telah dipaparkan bahwa pendapat Eagleton (2002:7) yang secara tegas menyatakan bahwa karya sastra adalah bentuk-bentuk persepsi, cara khusus dalam memandang dunia; dan juga memiliki relasi dengan cara memandang realitas yang menjadi mentalitas atau ideologi sosial suatu zaman telah terbukti melalui analisis yang telah dilakukan terhadap kedua cerpen ini. Negara yang begitu hegemonik pada zaman Orde Baru serta kemerosotan wacana kuasa tersebut dalam era reformasi telah digambarkan dengan baik dalam kedua cerpen tersebut.

\section{DAFTAR PUSTAKA}

Ajidarma, Seno Gumira. 2014. "Aku, Pembunuh Munir!” dalam Senja dan
Cinta yang Berdarah. Jakarta: Gramedia Pustaka Utama.

Ajidarma, Seno Gumira. 2006. "Saksi Mata" dalam Trilogi Insiden. Yogyakarta: Bentang Pustaka.

Eagleton, Terry. 2010. Teori Sastra: Sebuah Pengantar Komprehensif.

Yogyakarta: Jalasutra

Hasanuddin. 1996. Drama Karya dalam Dua Dimensi.Bandung: $\quad$ Penerbit Angkasa.

Narbuko, Cholid dan Abu Achmadi. 2010. Metodologi Penelitian. Jakarta: Bumi Aksara.

Sarup, Madan. 2003. Posstrukturalisme dan Posmodernisme: Sebuah Pengantar (terj) Medhy Aginta Hidayat. Yogyakarta: Jendela.

Sedarmayanti dan Syarifudin Hidayat. 2002. Metodologi Penelitian. Bandung: Mandar Maju. 